\title{
Influence of Varieties and Herbicide Mixtures on Wheat Based Cropping System in Relation to Phytotoxicity and Residual Soil Nutrients
}

\author{
${\text { Sarita } \text { Rani }^{1}{ }^{*} \text {, Suresh Kumar }}^{1}$, V.S. Hooda ${ }^{1}$, and Jagdish Parshad ${ }^{2}$ \\ ${ }^{1}$ Department of Agronomy, ${ }^{2}$ Department of Microbiology, \\ CCS Haryana Agricultural University, Hisar- (125004), Haryana, India \\ *Corresponding author
}

\section{A B S T R A C T}

Keywords

Wheat, Metribuzin,

Clodinafop,

Pinoxaden,

Fenoxaprop,

Phytotoxicity, Soil

nutrients

Article Info

Accepted:

25 May 2018

Available Online:

10 June 2018

An experiment was conducted at Research Farm of CCS Haryana Agricultural University, Hisar Haryana (India) during 2014-15 and 2015-16, to study the influence of varieties and herbicide mixtures on wheat in relation to phytotoxicity and residual soil nutrients. The treatments consisting of five varieties of wheat viz., WH 1105, HD 2967, DPW 621-50, WH 1124 and DBW 17 in main plots and six weed management practices i.e. metribuzin $\left(210 \mathrm{~g} \mathrm{ha}^{-1}\right)$, metribuzin+fenoxaprop $\left(150+100 \mathrm{~g} \mathrm{ha}^{-1}\right)$, metribuzin+pinoxaden $\left(150+40 \mathrm{~g} \mathrm{ha}^{-1}\right)$, metribuzin+clodinafop $\left(150+45 \mathrm{~g} \mathrm{ha}^{-1}\right)$, weed free and weedy check in sub-plots in split plot design with three replications. All the herbicide treatments were applied at 35 days after sowing (DAS) of wheat. No phytotoxic effect of any of the herbicidal treatments was observed on crop during both years except appearance of some spots on leaves of wheat variety HD 2967 after spray in plots treated with metribuzin alone and tank mix application of metribuzin + fenoxaprop, which didn't show any effect on yield of the crop. There was no significant effect of weed management practices on residual organic carbon $(\%)$, available $\mathrm{P}_{2} \mathrm{O}_{5}$, and $\mathrm{K}_{2} \mathrm{O}$ during both the years, however, available soil $\mathrm{N}$ after crop harvest was significantly lower in weed free plots as compared to all the herbicides treated and weed free plots during both the years.

\section{Introduction}

Wheat (Triticum aestivum L) is the second most important staple food crop cultivated in the world with $223.66 \mathrm{~m}$ ha area of cultivation, $735.26 \mathrm{~m}$ tonnes production with average productivity of $3290 \mathrm{~kg} / \mathrm{ha}$ during 2015-16. It stands third after maize and rice in the world (USDA, 2017). It is the basic foodstuff of the developing countries and major commodity in the world food trade (Hussain et. al., 2012). India is second leading country in wheat production (86.53 m tones) from an area of $31.47 \mathrm{~m}$ ha with an average productivity of $2750 \mathrm{~kg} / \mathrm{ha}$ (USDA, 2017). Out of total 18 species of the genus Triticum, 12 are cultivated species and in India, 3 species of wheat Triticum aestivum, Triticum 
durum and Triticum dicoccum are cultivated with 87, 12 and 1 percent contribution, respectively. In India, Uttar Pradesh ranks first in terms of area as well as production and Haryana ranks second after Punjab in productivity (4.4 t/ha) with $2.58 \mathrm{mha}$ area and $11.35 \mathrm{mt}$ production of wheat (Anonymous, 2018). The increasing demands of rising population require not only sustaining wheat production but also further increasing it with high potential. The best way to increase the wheat production is to reduce the agricultural losses with increasing production. In India, among the annual agricultural losses, weeds account for 45 per cent followed by, insects 30 per cent, diseases 20 per cent and other 5 per cent in wheat (Kler et. al., 2002). So, weeds are a major problem to crop production and are accountable for maximum losses caused by all the pests. Weed competition is one of the most important constraints in crop production as weeds compete with crop plants for moisture, nutrients, light and space, thereby depriving the crop of vital inputs. (Chhokar et. al., 2012). Up to $51 \%$ of reduction in grain yield in weedy check plot compared to treated plots was observed in wheat (Singh et. al. 2015). Among the weed control measures, herbicidal control plays an important role in close row crops, where manual or mechanical weeding is not feasible (Yaduraju and Mishra, 2002). Mimicry grassy weeds cannot be weeded out manually or mechanically in wheat. Therefore, herbicidal control is more effective against grassy and broadleaf weeds in wheat. But continuous use of herbicide over several years certainly leads to elimination of sensitive weed species but leave out tolerant species resulting in gradual buildup of their population on account of herbicide resistance i.e. Phalaris minor against isoproturon (Malik and Singh, 1995). Due to the large scale failure of isoproturon, danger of development of rapid resistance and cross-resistance against alternate herbicides due to their continuous use, non-adoption of herbicides like pendimethalin by farmers because of its high cost and requirement for high moisture at the time of spray, phytotoxicity due to high doses of metribuzin and proportionate changes in weed flora in cereal crops necessitates using herbicide mixtures (Yadav et. al., 2002; Sharma et. al., 2002; Yadav and Malik, 2005; Chhipa and Nepalia, 2015).

Crop cultivars possessing traits such as fast germination, quick growth, large leaf area and high biomass have a competitive advantage over weeds. Sowing such cultivars has been shown to suppress weeds in various crops (Sardana et. al., 2017). Competitive cultivars can reduce weed growth in the standing crop, curtail weed seed production, prevent future weed infestation and may serve as a low cost tool in weed management (Kumar et. al., 2013). Careful selections of a competitive crop/genotype can potentially suppress weed growth without sacrificing crop yield (Ramesh et. al., 2017). Cultivars of several crops including winter wheat differ considerably in their tolerance to metribuzin (Runyan et. al., 1982). Differential varietal sensitivity to fenoxaprop + metribuzin has been reported (Yadav et. al., 2012) and it is suggested to determine varietal sensitivity of fenoxaprop + metribuzin before use in field conditions (Yadav et. al., 2016). Reduction in wheat yield by 23 percent with application of metribuzin at $210 \mathrm{~g} \mathrm{ha}^{-1}$ was reported when applied at 60 over 38 DAS (Singh et. al. 2011). Choudhary et. al. (2016) found lowest harvest index in metribuzin $200 \mathrm{~g} / \mathrm{ha}$ as compared to all other herbicidal treatments, which was attributed to phytotoxic effect of metribuzin on wheat cultivar 'PBW-343'. Keeping this in view present investigation was conducted to study the impact of wheat varieties and weed management practices in relation to herbicide phytotoxicity and residual soil nutrients. 


\section{Materials and Methods}

An experiment was conducted during 2014-15 and 2015-16 at research farm, CCS Haryana Agricultural University, Hisar, Haryana (India) situated at $29^{\circ} 10^{\prime} \mathrm{N}$ latitude and $75^{\circ} 46^{\prime}$ E longitude at an elevation of $215.2 \mathrm{~m}$ above mean sea level in a semiarid climate. The upper soil layer of the experimental field was sandy loam, low in OC $(0.41 \%)$ and nitrogen $(212 \mathrm{~kg} / \mathrm{ha})$, medium in $\mathrm{P}_{2} \mathrm{O}_{5}(16.6 \mathrm{~kg} / \mathrm{ha})$ and high in $\mathrm{K}_{2} \mathrm{O}(408 \mathrm{~kg} / \mathrm{ha})$ with slightly alkaline in $\mathrm{pH}$ (8.3). The experiment was laid out in split plot design with three replications. The treatments consisting of five varieties of wheat viz. WH 1105, HD 2967, DPW 621-50, WH 1124 and DBW 17 in main plots and six weed management practices i.e. metribuzin $(210 \mathrm{~g}$ $\left.\mathrm{ha}^{-1}\right)$, metribuzin+fenoxaprop $\left(150+100 \mathrm{~g} \mathrm{ha}^{-}\right.$ $\left.{ }^{1}\right)$, metribuzin+pinoxaden $\left(150+40 \mathrm{~g} \mathrm{ha}^{-1}\right)$, metribuzin+clodinafop $\left(150+45 \mathrm{~g} \mathrm{ha}^{-1}\right)$, weed free and weedy check in sub-plots. All the herbicide treatments were applied at 35 DAS of wheat, preparing herbicide combinations by tank-mixing and repeated manual weedings were practiced for maintaining the weed free plots. Fodder maize was planted after the harvest of wheat crop. The data on plant height of wheat and fodder maize, and grain yield of wheat were collected at different stages and statistically analyzed. Visual surveillance was undertaken to observe crop injury in wheat and maize. Soil analysis was done at the start and harvest of crop. The mean weekly weather data for the wheat-fodder maize cropping seasons 2014-15 and 2015-16 have been given in Fig. 1 and 2.

\section{Results and Discussion}

\section{Herbicide phytotoxicity to wheat crop (0-10 scale)}

Visual phytotoxicity (0-10 scale) recorded at 10 and 20 days after spraying indicated that there was no phytotoxic effect of any of the herbicidal treatments on crop during both years. However, some freckles/ spots appeared on leaves of wheat variety HD 2967 after spray in plots treated with metribuzin $210 \mathrm{~g}$ $\mathrm{ha}^{-1}$ and tank mix application of metribuzin + fenoxaprop $150+100 \mathrm{~g} \mathrm{ha}^{-1}$, which disappeared within 1-2 weeks, and had no effect on the crop (Table 1).

\section{Plant height (cm)}

At 120 DAS, maximum plant height was recorded in wheat variety HD $2967(97.9 \mathrm{~cm}$ and $94.7 \mathrm{~cm}$ ), which was statistically at par with all varieties except DBW $17(83.4 \mathrm{~cm}$ and $79.7 \mathrm{~cm}$ ) during 2014-15 and 2015-16, respectively (Table 2). WH 1105, DPW 62150 were at par with HD 2967 in respect of plant height during both the years. Marked differences were recorded in the plant height with different weed management practices, maximum being with the weed free treatment (96.5 and $93.8 \mathrm{~cm}$ during 2014-15 and 201516, respectively). Among herbicidal treatments, combination of metribuzin with fenoxaprop produced tallest plants and was at par with weed free plots as well as combination of metribuzin with pinoxaden or clodinafop, but significantly taller than with metribuzin applied alone and weedy check during both the years. Weedy check plots resulted in significantly lower plant height of wheat as compared to all the herbicidal treatments during both years.

Plant height of succeeding fodder maize crop at 30 DAS was statistically similar to each other in all the plots of different preceding wheat varieties and did not show any significant difference during 2014-15 and 2015-16 (Table 2). There was no significant effect of different weed management practices applied in wheat on the plant height of succeeding fodder maize crop at 30 DAS during both the years. 


\section{Grain yield (kg/ha)}

Wheat variety WH 1105 proved its superiority by producing grain yield $(5855$ and $5401 \mathrm{~kg}$ $\mathrm{ha}^{-1}$ during 2014-15 and 2015-16, respectively) being at par with HD 2967 and DPW 621-50, but statistically better than DBW 17 and WH 1124 (Table 2). WH 1124 showed the lowest grain yield and significantly lower than all the varieties during both the years. The weed management practices significantly influenced the wheat grain yield during both the years. The maximum grain yield was recorded in weed free plots (6284 and $5902 \mathrm{~kg} \mathrm{ha}^{-1}$ during 201415 and 2015-16, respectively). Weedy check plots produced the minimum grain yield (4176 and $3781 \mathrm{~kg} \mathrm{ha}^{-1}$ during 2014-15 and 2015-16, respectively) and was significantly lower than all the weed management practices. Among herbicidal treatments, metribuzin + fenoxaprop $\left(150+100 \mathrm{~g} \mathrm{ha}^{-1}\right)$ produced the maximum grain yield and it was statistically at par with weed free plots and remaining two combination treatments i.e., metribuzin + pinoxaden $\left(150+\mathrm{g} \mathrm{ha}^{-1}\right)$ and metribuzin + clodinafop $\left(150+45 \mathrm{~g} \mathrm{ha}^{-1}\right)$. Metribuzin $(210$ $\mathrm{g} \mathrm{ha}^{-1}$ ) produced significantly better grain yield as compared to weedy check, but it was inferior to combination treatments of metribuzin and other herbicides in terms of grain yield (Table 2 ).

Fig.1 Mean weekly weather data for wheat-fodder maize cropping seasons 2014-15

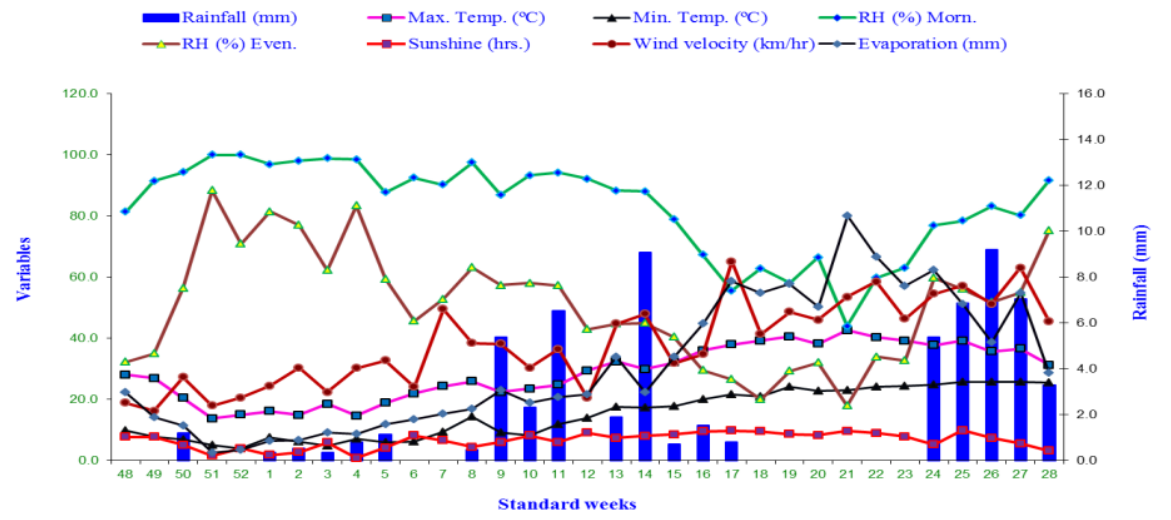

Fig.2 Mean weekly weather data for wheat-fodder maize cropping seasons 2015-16

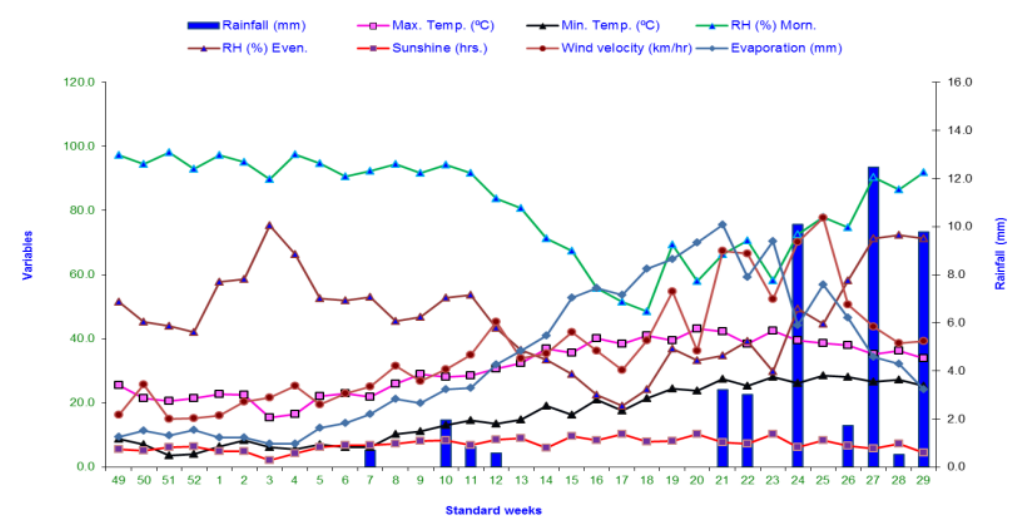


Table.1 Herbicide phytotoxicity to wheat crop (0-10 scale)

\begin{tabular}{|c|c|c|c|c|c|}
\hline \multirow[t]{2}{*}{ Variety } & \multirow[t]{2}{*}{ Treatments } & \multicolumn{2}{|c|}{ 2014-15 } & \multicolumn{2}{|c|}{ 2015-16 } \\
\hline & & 10 DAT & 20 DAT & 10 DAT & 20 DAT \\
\hline WH 1105 & MBZ $210 \mathrm{~g} \mathrm{ha}^{-1}$ & 0 & 0 & 0 & 0 \\
\hline WH 1105 & $\mathrm{MBZ}+\mathrm{CDF}(150+45) \mathrm{g} \mathrm{ha}^{-1}$ & 0 & 0 & 0 & 0 \\
\hline WH 1105 & $\mathrm{MBZ}+\mathrm{PDN}(150+40) \mathrm{g} \mathrm{ha}^{-1}$ & 0 & 0 & 0 & 0 \\
\hline WH 1105 & $\mathrm{MBZ}+\mathrm{FNP}(150+100) \mathrm{g} \mathrm{ha}^{-1}$ & 0 & 0 & 0 & 0 \\
\hline WH 1105 & Weed free & 0 & 0 & 0 & 0 \\
\hline WH 1105 & Weedy check & 0 & 0 & 0 & 0 \\
\hline HD 2967 & MBZ $210 \mathrm{~g} \mathrm{ha}^{-1}$ & 2 & 0 & 3 & 1 \\
\hline HD 2967 & $\mathrm{MBZ}+\mathrm{CDF}(150+45) \mathrm{g} \mathrm{ha}^{-1}$ & 0 & 0 & 0 & 0 \\
\hline HD 2967 & $\mathrm{MBZ}+\mathrm{PDN}(150+40) \mathrm{g} \mathrm{ha}^{-1}$ & 0 & 0 & 0 & 0 \\
\hline HD 2967 & $\mathrm{MBZ}+\mathrm{FNP}(150+100) \mathrm{g} \mathrm{ha}^{-1}$ & 2 & 0 & 2 & 0 \\
\hline HD 2967 & Weed free & 0 & 0 & 0 & 0 \\
\hline HD 2967 & Weedy check & 0 & 0 & 0 & 0 \\
\hline DPW 621-50 & MBZ $210 \mathrm{~g} \mathrm{ha}^{-1}$ & 0 & 0 & 0 & 0 \\
\hline DPW 621-50 & $\mathrm{MBZ}+\mathrm{CDF}(150+45) \mathrm{g} \mathrm{ha}^{-1}$ & 0 & 0 & 0 & 0 \\
\hline DPW 621-50 & $\mathrm{MBZ}+\mathrm{PDN}(150+40) \mathrm{g} \mathrm{ha}^{-1}$ & 0 & 0 & 0 & 0 \\
\hline DPW 621-50 & $\mathrm{MBZ}+\mathrm{FNP}(150+100) \mathrm{g} \mathrm{ha}^{-1}$ & 0 & 0 & 0 & 0 \\
\hline DPW 621-50 & Weed free & 0 & 0 & 0 & 0 \\
\hline DPW 621-50 & Weedy check & 0 & 0 & 0 & 0 \\
\hline WH 1124 & MBZ $210 \mathrm{~g} \mathrm{ha}^{-1}$ & 0 & 0 & 0 & 0 \\
\hline WH 1124 & $\mathrm{MBZ}+\mathrm{CDF}(150+45) \mathrm{g} \mathrm{ha}^{-1}$ & 0 & 0 & 0 & 0 \\
\hline WH 1124 & $\mathrm{MBZ}+\mathrm{PDN}(150+40) \mathrm{g} \mathrm{ha}^{-1}$ & 0 & 0 & 0 & 0 \\
\hline WH 1124 & $\mathrm{MBZ}+\mathrm{FNP}(150+100) \mathrm{g} \mathrm{ha}^{-1}$ & 0 & 0 & 0 & 0 \\
\hline WH 1124 & Weed free & 0 & 0 & 0 & 0 \\
\hline WH 1124 & Weedy check & 0 & 0 & 0 & 0 \\
\hline DBW 17 & MBZ $210 \mathrm{~g} \mathrm{ha}^{-1}$ & 0 & 0 & 0 & 0 \\
\hline DBW 17 & $\mathrm{MBZ}+\mathrm{CDF}(150+45) \mathrm{g} \mathrm{ha}^{-1}$ & 0 & 0 & 0 & 0 \\
\hline DBW 17 & $\mathrm{MBZ}+\mathrm{PDN}(150+40) \mathrm{g} \mathrm{ha}^{-1}$ & 0 & 0 & 0 & 0 \\
\hline DBW 17 & $\mathrm{MBZ}+\mathrm{FNP}(150+100) \mathrm{g} \mathrm{ha}^{-1}$ & 0 & 0 & 0 & 0 \\
\hline DBW 17 & Weed free & 0 & 0 & 0 & 0 \\
\hline DBW 17 & Weedy check & 0 & 0 & 0 & 0 \\
\hline
\end{tabular}

Abbreviations: MBZ, metribuzin; CDF, clodinafop; PDN, pinoxaden; FNP, fenoxaprop; 
Table.2 Effect of different weed control treatments on plant height of wheat, grain yield 2014-15 and 2015-16

\begin{tabular}{|c|c|c|c|c|c|c|}
\hline \multirow[t]{2}{*}{ Treatments } & \multicolumn{2}{|c|}{$\begin{array}{l}\text { Plant height } \\
\text { wheat }(\mathrm{cm}) \text { at } \\
120 \text { DAS }\end{array}$} & \multicolumn{2}{|c|}{$\begin{array}{c}\text { Plant height } \\
\text { maize }(\mathrm{cm}) \text { at } 30 \\
\text { DAS }\end{array}$} & \multicolumn{2}{|c|}{$\begin{array}{l}\text { Wheat grain yield } \\
\qquad\left(\mathrm{kg} \mathrm{ha}^{-1}\right)\end{array}$} \\
\hline & 2014-15 & 2015-16 & 2014-15 & 2015-16 & 2014-15 & 2015-16 \\
\hline \multicolumn{7}{|l|}{ A. Varieties } \\
\hline WH 1105 & 95.9 & 94.3 & 65.5 & 64.3 & 5855 & 5401 \\
\hline HD 2967 & 97.9 & 94.7 & 64.2 & 64.1 & 5778 & 5297 \\
\hline DPW 621-50 & 96.6 & 93.0 & 67.1 & 67.5 & 5701 & 5222 \\
\hline WH 1124 & 95.2 & 92.3 & 66.6 & 67.3 & 5153 & 4782 \\
\hline DBW 17 & 83.4 & 79.7 & 64.2 & 65.3 & 5460 & 5048 \\
\hline SEm \pm & 0.9 & 1.0 & 1.7 & 1.6 & 67 & 79 \\
\hline $\operatorname{CD}(5 \%)$ & 2.8 & 3.0 & NS & NS & 223 & 261 \\
\hline \multicolumn{7}{|l|}{ B. Weed Management } \\
\hline MBZ $210 \mathrm{~g} \mathrm{ha}^{-1}$ & 93.0 & 89.9 & 65.0 & 64.9 & 5153 & 4733 \\
\hline $\mathrm{MBZ}+\mathrm{CDF}(150+45) \mathrm{g} \mathrm{ha}^{-1}$ & 94.0 & 90.7 & 65.4 & 64.5 & 5926 & 5436 \\
\hline $\mathrm{MBZ}+$ PDN $(150+40) \mathrm{g} \mathrm{ha}^{-1}$ & 94.9 & 91.7 & 65.2 & 65.2 & 5967 & 5501 \\
\hline $\mathrm{MBZ}+\mathrm{FNP}\left(150\right.$ + 100) $\mathrm{g} \mathrm{ha}^{-1}$ & 95.8 & 92.5 & 65.2 & 65.8 & 6032 & 5547 \\
\hline Weed free & 96.5 & 93.8 & 66.4 & 66.4 & 6284 & 5902 \\
\hline Weedy check & 88.5 & 86.2 & 65.9 & 67.2 & 4176 & 3781 \\
\hline SEm \pm & 0.8 & 0.7 & 1.2 & 1.2 & 139 & 165 \\
\hline $\operatorname{CD}(5 \%)$ & 2.3 & 2.1 & NS & NS & 397 & 469 \\
\hline
\end{tabular}


Table.3 Effect of varieties and weed management practices in wheat on organic carbon and N, P, K availability in soil

\begin{tabular}{|c|c|c|c|c|}
\hline \multirow[t]{2}{*}{ Treatments } & $\mathrm{OC}(\%)$ & $\begin{array}{c}\text { Available } \mathbf{N} \\
\quad\left(\mathrm{kg} \mathrm{ha}^{-1}\right)\end{array}$ & $\begin{array}{c}\text { Available } \mathrm{P}_{2} \mathrm{O}_{5} \\
\left(\mathrm{~kg} \mathrm{ha}^{-1}\right)\end{array}$ & $\begin{array}{c}\text { Available } \mathrm{K}_{2} \mathrm{O} \\
\left(\mathrm{kg} \mathrm{ha}^{-1}\right)\end{array}$ \\
\hline & \multicolumn{4}{|c|}{ 2014-15 } \\
\hline \multicolumn{5}{|l|}{ A. Varieties } \\
\hline WH 1105 & 0.35 & 205.6 & 14.6 & 402.0 \\
\hline HD 2967 & 0.36 & 207.3 & 15.1 & 397.0 \\
\hline DPW 621-50 & 0.37 & 209.3 & 15.6 & 406.0 \\
\hline WH 1124 & 0.41 & 212.6 & 16.5 & 410.0 \\
\hline DBW 17 & 0.40 & 212.0 & 16.2 & 408.0 \\
\hline SEm \pm & 0.20 & 1.1 & 0.7 & 4.3 \\
\hline CD $(5 \%)$ & NS & 3.2 & NS & NS \\
\hline \multicolumn{5}{|l|}{ B. Weed Management } \\
\hline MBZ $210 \mathrm{~g} \mathrm{ha}^{-1}$ & 0.38 & 211.4 & 16.3 & 409.0 \\
\hline $\mathrm{MBZ}+\mathrm{CDF}(150+45) \mathrm{g} \mathrm{ha}^{-1}$ & 0.37 & 209.8 & 15.9 & 407.0 \\
\hline $\mathrm{MBZ}+$ PDN $(150+40) \mathrm{g} \mathrm{ha}^{-1}$ & 0.37 & 208.9 & 15.3 & 404.0 \\
\hline $\mathrm{MBZ}+\mathrm{FNP}(150+100) \mathrm{g} \mathrm{ha}^{-1}$ & 0.39 & 208.1 & 15.1 & 402.0 \\
\hline Weed free & 0.41 & 205.3 & 14.4 & 395.0 \\
\hline Weedy check & 0.36 & 212.5 & 16.6 & 410.0 \\
\hline SEm \pm & 0.20 & 2.1 & 0.8 & 4.3 \\
\hline \multirow[t]{2}{*}{$\mathrm{CD}(5 \%)$} & NS & 6.0 & NS & NS \\
\hline & \multicolumn{4}{|c|}{ 2015-16 } \\
\hline \multicolumn{5}{|l|}{ A. Varieties } \\
\hline WH 1105 & 0.34 & 203.1 & 14.7 & 399.0 \\
\hline HD 2967 & 0.35 & 204.2 & 15.3 & 395.0 \\
\hline DPW 621-50 & 0.36 & 207.7 & 15.5 & 403.0 \\
\hline WH 1124 & 0.40 & 212.1 & 16.8 & 407.0 \\
\hline DBW 17 & 0.40 & 211.1 & 16.3 & 406.0 \\
\hline SEm \pm & 0.20 & 1.4 & 0.8 & 4.2 \\
\hline CD $(5 \%)$ & NS & 4.2 & NS & NS \\
\hline \multicolumn{5}{|l|}{ B. Weed Management } \\
\hline MBZ $210 \mathrm{~g} \mathrm{ha}^{-1}$ & 0.36 & 211.2 & 16.4 & 406.0 \\
\hline $\mathrm{MBZ}+\mathrm{CDF}(150+45) \mathrm{g} \mathrm{ha}^{-1}$ & 0.37 & 208.9 & 16.0 & 405.0 \\
\hline $\mathrm{MBZ}+\mathrm{PDN}(150+40) \mathrm{g} \mathrm{ha}^{-1}$ & 0.38 & 206.4 & 15.4 & 401.0 \\
\hline $\mathrm{MBZ}+\mathrm{FNP}(150+100) \mathrm{g} \mathrm{ha}^{-1}$ & 0.38 & 205.3 & 15.2 & 398.0 \\
\hline Weed free & 0.40 & 201.1 & 14.5 & 394.0 \\
\hline Weedy check & 0.35 & 212.9 & 16.8 & 408.0 \\
\hline SEm \pm & 0.20 & 3.1 & 0.9 & 4.6 \\
\hline CD $(5 \%)$ & NS & 9.4 & NS & NS \\
\hline
\end{tabular}




\section{Residual nutrients in soil}

Soil analysis data (Table 3) taken at harvest of crop revealed that no significant difference due to any of the varieties or weed management practices was observed on organic carbon (\%), available $\mathrm{P}_{2} \mathrm{O}_{5}$ and $\mathrm{K}_{2} \mathrm{O}$ during both the years, however, available $\mathrm{N}$ was significantly affected by the treatments. Maximum available nitrogen was found in plots where wheat variety WH 1124 (212.6 and $212.1 \mathrm{~kg} \mathrm{ha}^{-1}$ ) was grown being at par with DBW 17 and differed significantly from the plots of rest of wheat varieties during 2014-15 and 2015-16, respectively. Availability of soil nitrogen was significantly lower in weed. free plots as compared to plots with metribuzin application and weedy check plots during both the years. Weedy check plots recorded highest available nitrogen (212.5 and $211.9 \mathrm{~kg} \mathrm{ha}^{-1}$ ) during 2014-15 and 2015-16, respectively.

In conclusion, any of the herbicide treatment did not exhibit serious phytotoxicity to any of the wheat varieties (except minor effect on variety HD 2967 which recovered quickly and didn't affect the plant height and grain yield) in experiment however herbicidal sensitivity needs to be determined before using in the field conditions. There was no significant effect of weed management practices on residual organic carbon (\%), available $\mathrm{P}_{2} \mathrm{O}_{5}$, and $\mathrm{K}_{2} \mathrm{O}$ during both the years.

\section{Acknowledgement}

We are thankful to Dr. Jagdev Singh, Professor and Head, Department of Agronomy for providing necessary facilities and help rendered by staff during the research is gratefully acknowledged. The guidance and appraisal of Dr. Samunder Singh and the advisory committee members Dr. R.K. Nanwal, Dr. K.D. Sharma, Dr. P.S. Sangwan and Dr. R.S. Dhillon is thankfully acknowledged.

\section{References}

Anonymous, 2018. Statistical Abstract of Haryana 2016-17. Department of Economic and Statistical Analysis, Haryana.

Chhipa, K. G. and Nepalia, V. 2015. Effect of weed control and phosphorus sources on productivity of wheat (Triticum aestivum). Indian J. Agric. Res. 49 (2): 180-184.

Chhokar, R. S., Sharma, R. K., Sharma, I. 2012. Weed management strategies in wheat- A review. J. Wheat Res 4: 121.

Choudhary, D., Singh, P. K., Chopra, N. K. and Rana S. C. 2016. Effect of herbicides and herbicide mixtures on weeds in wheat. Indian J. Agric. Res. 50 (2): 107-112.

Hussain, M., Niaz, M., Iqbal, M., Iftikhar, T. and Ahmad., J. 2012. Emasculation techniques and detached tiller culture in wheat X maize crosses. J. Agric. Res., 50 (1): 1-19.

Kler, D. S., Kaur, R. and Kaur, G. 2002. Planting techniques and plant density for weed control in wheat- A review. Environment and Ecology 20 (4): 930941.

Kumar, S., Rana, S. S., Ramesh and Chander, N. 2013. Herbicide combinations for broad-spectrum weed control in wheat. Indian J. Weed Sci. 45 (1): 29 33.

Malik, R. K. and Singh, S. 1995. Littleseed canary grass (Phalaris minor) resisitance to isoproturon in India. Weed Technol. 9: 419-425.

Ramesh, K., Rao, A. N. and Chauhan, B. S. 2017. Role of crop competition in managing weeds in rice, wheat, and maize in India: A review. Crop protection 95: 14-21.

Runyan, T. J., McNeil, W. K. and Peeper, T. F. 1982. Differential tolerance of 
wheat (Triticum aestivum) cultivars to metribuzin. Weed Science 30: 94-97.

Sardana, V., Mahajan, G., Jabran, K. and Chauhan, B. S. 2017. Role of competition in managing weeds: An introduction to the special issue. Crop Protection 95: 1-7.

Sharma, R., Pahuja, S. S., Balyan, R. S., Malik, R. K. 2002. Effect of sulfonylurea herbicides applied alone and tank-mix with metribuzin on weeds and their residual effect on succeeding crop of sorghum. Indian J. Weed Sci. 34: 178-183.

Singh, S., Dhaka, A. K. and Hooda, V. S. 2015. Evaluation of Traxos 5\% EC (Pinoxaden + Clodinofop propargyl) against Phalaris minor and other grassy weeds in Wheat. Haryana $J$. Agron. 31 (1\&2): 1-8.

Singh, S., Singh, K., Punia, S. S., Yadav, A. and Dhawan, R. S. 2011. Effect of stage of Phalaris minor on the efficacy of accord plus (fenoxaprop + metsulfuron, ready-mix). Indian $J$. Weed Sci. 43: 23-31.

USDA (2017): World Agricultural Production, USDA, USA.

Yadav, A. and Malik, R. K. 2005. Herbicideresistant Phalaris minor in wheat - A sustainability issue. Resourse Book. Department of Agronomy and Directorate of Extension Education, CCSHAU, Hisar, India. P. 152.

Yadav, A., Hooda, V. S., Bir, Dharam, Duhan, A., 2012. Screening the sensitivity of wheat varieties against fenoxaprop + metribuzin. In: Proc. National Seminar on Sustainable Agriculture and Food Security: Challenges in Changing Climate March, 27-28 2012. Directorate of Research, CCS HAU, Hisar, Pp. 255256.

Yadav, A., Malik, R. K., Chauhan, B. S., Gill, G. 2002. Present status of herbicide resistance in Haryana. In: Malik, R.K., Balyan, R.S., Yadav, A., Pahwa, S.K. (Eds.), Proc. Int. Workshop on Herbicide Resistance Management and Zero-tillage in Rice- Wheat Cropping System, March, 4-6, 2002. CCS HAU, Hisar, India, Pp. 15-22.

Yadav, D. B., Yadav, A., Punia, S. S. and Chauhan, B. S. 2016. Management of herbicide-resistant Phalaris minor in wheat by sequential or tank-mix applications of pre- and postemergence herbicides in NorthWestern Indo-Gangetic Plains. Crop Protection 89: 239-247.

Yaduraju, N. T. and Mishra, J. S. 2002. Zero tillage in rice-wheat cropping system on vertisols in Madhya Pradesh prospects and problems, Pp.117-119. In: Proceedings of International Workshop on "Herbicide Resistance Management and Zero Tillage in RiceWheat Cropping System. CCS HAU, Hisar, India. March, 4-6, 2002.

\section{How to cite this article:}

Sarita Rani, Suresh Kumar, V.S. Hooda, and Jagdish Parshad. 2018. Influence of Varieties and Herbicide Mixtures on Wheat Based Cropping System in Relation to Phytotoxicity and Residual Soil Nutrients. Int.J.Curr.Microbiol.App.Sci. 7(06): 3573-3581. doi: https://doi.org/10.20546/ijcmas.2018.706.420 